Балахтар В. В.

\title{
СОЦІАЛЬНО-ПСИХОЛОГІЧНІ ОСОБЛИВОСТІ КОМУНІКАТИВНОЇ ТОЛЕРАНТНОСТІ ФАХІВЦІВ 3 СОЦІАЛЬНОЇ РОБОТИ НА РІЗНИХ СТАДІЯХ ПРОФЕСІЙНОГО СТАНОВЛЕННЯ
}

\begin{abstract}
Балахтар В. В. Соціально-психологічні особливості комунікативної толерантності фахівців соціальної роботи на різних стадіях професійного становлення. У статті висвітлено соціальнопсихологічні особливості комунікативної толерантності фахівиів з соџіальної роботи. На основі результатів емпіричного дослідження визначено рівень комунікативної толерантності та рівень інтолерантності залежно від статі, місия проживання фахівців, стадї професійного становлення («самовизначення в якості фахівия»; «стадія самопроектування (життєконструювання) професійного иляху»; "саморегуляиії у професійній діяльності»; «саморозвитку, самоствердження та самовдосконалення у професійній діяльності»; «самореалізація фахівия як професіонала, досягнення «акме»; "рефлексія професійного досвіду та самотворення смислу подальшого життєвого шляху»).

Ключові слова: комунікативна толерантність, інтолерантність, фахівець з соиіальної роботи, стадії професійного становлення, самовизначення, саморегуляція, самопроектування, самоствердження, самовдосконалення, саморегулячія, самореалізація, рефлексія.
\end{abstract}

Балахтар В. В. Социально-психологические особенности коммуникативной толерантности специалистов социальной работы на разных стадиях профессионального становления. В статье освещены социально-психологические особенности коммуникативной толерантности специалистов по сочиальной работе. На основе результатов эмпирического исследования определен уровень коммуникативной толерантности и уровень интолерантности в зависимости от пола, места проживания спещиалистов, стадии профессионального становления («самоопределение в качестве специалиста», «стадия самопроектирования (жизнеконструирования) профессионального пути», «саморегуляции в профессиональной деятельности», «саморазвития, самоутверждения $u$ самосовершенствования в профессиональной деятельности», «самореализация специалиста как профессионала, достижения «акме», «рефлексия профессионального опыта и самосозидание смысла дальнейтего жизненного пути»).

Ключевые слова: коммуникативная толерантность, интолерантность, специалист по сочиальной работе, стадии профессионального становления, самоопределения, самопроектирование, самоутверждение, самосовершенствование, саморегулячия, самореализачия, рефлексия.

Постановка проблеми. 3 розвитком України як демократичної, соціальної і правової держави зростає потреба у підготовці фахівців соціальної сфери, які б відзначалися чітко вираженою професійною спрямованістю, високим інтелектуальним рівнем, творчістю, здатністю до постійного розвитку, вдосконалення, аналізу проблем вразливих категорій населення, планування роботи як соціальних працівників, так і соціальної служби загалом, відданістю загальнолюдським і національним ідеям. Одним із найбільш важливих аспектів реалізації соціальної роботи виступає професіоналізм фахівця, що володіє комунікативною компетентністю, заснованою на толерантності, яка посідає особливе місце у сфері соціальної роботи, є універсальним принципом, однією з основних цінностей людської життєдіяльності, професійно важливою якістю особистості фахівця на всіх стадіях його професійного становлення і являє собою «ставлення особистості до інших людей, їхніх психологічних станів, до їхніх якостей і вчинків у ситуаціях комунікативної взаємодії з домінантною спрямованістю свідомості на терпиму, безконфліктну комунікативну поведінку, на особливий, доброзичливий тип взаємодії індивіда з іншими людьми» [1, с. 266-267; 10, с. 68-71]. Аналізуючи сучасну теорію і практику, можна стверджувати про недостатність вивчення і розробки комунікативної толерантності, зростання уваги до соціально-психологічних особливостей формування толерантних взаємин загалом і на різних стадіях професійного становлення фахівців з соціальної роботи зокрема. 
Аналіз останніх досліджень і публікацій. Проблему комунікативної толерантності порушували у своїх дослідженнях чимало науковців, тому діапазон підходів досить широкий: психологічний (Ш. Берн [4], В. Бойко [5], Е. Виноградова [6], Г. Солдатова, О. Кравцова [12] та ін.), компетентнісний (Г. Балл [1], О. Бондарчук [7] та ін.), педагогічний (Р. Вайнола [8], В. Баранюк [3], Л. Харченко [15] та ін.) тощо. Проте, як свідчить аналіз їхніх праць, кількість наукових досліджень, присвячених формуванню комунікативної толерантності у сучасних фахівців з соціальної роботи, не $\epsilon$ достатньою. Одним із важливих чинників ефективної діяльності соціального працівника $є$ взаємодія з клієнтами на основі толерантності, яку науковці розглядали як соціальну цінність, норму соціального життя, поведінки, принцип людських взаємин, особистісну якість.

Метою статті є дослідження соціально-психологічних особливостей комунікативної толерантності фахівців з соціальної роботи на різних стадіях їхнього професійного становлення.

Методика та організація дослідження. У дослідженні взяли участь 625 фахівців 3 соціальної роботи з різних регіонів України на різних стадіях професійного становлення:

1) самовизначення в якості майбутнього фахівця - студенти віком до 23 років $(31,0 \%)$;

2) самопроектування (життєконструювання) майбутнього професійного шляху - молоді фахівці віком до 30 років $(15,0 \%)$;

3) саморегуляція у професійній діяльності - фахівці віком від 30 до 40 троків (16,3\%);

4) самоствердження та самовдосконалення у професійній діяльності - фахівці віком від 40 до 50 троків $(11,2 \%)$;

5) самореалізація фахівця як професіонала, досягнення «акме»- фахівці віком від 50 до 60 років (14,7\%);

6) рефлексія професійного досвіду і самотворення у після трудовому житті - фахівці віком від 60 років і більше $(11,7 \%)$.

3 них було виокремлено групи:

1) за статтю: жінки $(76,2 \%)$ і чоловіки $(23,8 \%)$;

2) за місцем проживання: місто $(75,7 \%)$ і село $(24,3 \%)$.

Під час дослідження використовувались такі методи: аналіз науково-методичної літератури в галузі освіти та соціальної роботи, методика діагностики комунікативної толерантності В. Бойка. Статистична обробка даних і графічна презентація результатів здійснювалася за допомогою пакета статистичних програм SPSS (версія 23.0).

Виклад основного матеріалу і результатів дослідження. Формування комунікативної толерантності у процесі становлення особистості фахівця з соціальної роботи на різних стадіях професійного становлення є складним, неперервним процесом активної взаємодії особистості та професійного середовища, що забезпечує ефективність професійної діяльності у сфері соціальної роботи, є основою професійного саморозвитку, самоосвіти, самовдосконалення й самореалізації. Загалом варто відзначити, що однозначного трактування поняття «толерантність» донині нема. У словниках з різних наук його найчастіше визначають як синонім «терпимості», посилаючись на те, що поняття «толерантність» $є$ похідною (з лат. toleranttia - терпимість). Науковці також порізному трактують поняття «комунікативна толерантність». Так, В. Бойко тлумачить його як професійну комунікативну толерантність, що «проявляється в робочій обстановці, у взаємодії 3 тими людьми, з якими доводиться мати справу за родом діяльності» [11].

На думку Е. Виноградової, «комунікативна толерантність є основною якістю особистості, що виявляється в терпимості, безконфліктності, а також стійкості, довірі і здатності спокійно і без роздратування приймати індивідуальності інших людей» [8, с. 23]. Комунікативна толерантність актуальна саме у сфері соціальної роботи, оскільки спілкування $є$ одним 3 найважливіших інструментів професійної діяльності фахівця. Як зазначає А. Капська, фахівець має досконало володіти знаннями і вміннями професійної комунікації, вміннями адекватно їх застосовувати у відповідній сфері і ситуації [9], уміти використовувати увесь набір «засобів, орієнтованих як на розвиток суб'єкт-суб'єктних продуктивних особистісних сторін спілкування, так і його суб'єкт-об'єктних репродуктивних, нераціональних складових (компонентів)» [2, c. 37-42]. На нашу думку, комунікативна толерантність $є$ однією 3 найголовніших рис 
особистості фахівця 3 соціальної роботи, що сприяє становленню його духовності й гуманістичної культури, вихованню терпимості, взаємоповаги, готовності до взаємодії, розкриття самоцінності людини, суті суб'єкт-суб'єктних відносин, пріоритетності розвитку особистості (клієнта і фахівця), що володіє почуттям власної гідності, внутрішньою волею й відповідальністю.

3 метою визначення соціально-психологічних особливостей комунікативної толерантності на різних стадіях професійного становлення було проведено дослідження серед фахівців з соціальної роботи. На першому етапі емпіричного дослідження за методикою В. Бойка були визначені показники та рівні комунікативної толерантності фахівців соціальної роботи (табл. 1).

Як випливає з даних табл. 1 комунікативна толерантність розвинута недостатньо. Високий рівень виявлено лише у 43,7\% досліджуваних, середній - у 55,3\%, а низький - у 1\%. Це свідчить про те, що у понад половини фахівців є утруднення у взаємодії з клієнтами. Зокрема, це виявляється у недостатньому вмінні приховувати неприємні почуття при взаємодії - 7,1\% респондентів, що свідчить про інтолерантний рівень комунікативної толерантності, 42,4\% мають середній рівень за цим показником, і лише 50,5\% опитаних показали толерантний рівень й уміння приховувати неприємні відчуття у процесі взаємодії з клієнтами у сфері соціальної роботи.

Рівні комунікативної толерантності фахівців соціальної роботи

Таблиия 1

\begin{tabular}{|l|c|c|c|}
\hline \multirow{2}{*}{\multicolumn{1}{|c|}{ Показники }} & \multicolumn{3}{c|}{$\begin{array}{c}\text { Рівні комунікативної толерантності } \\
\text { (кількість досліджуваних у \%) }\end{array}$} \\
\cline { 2 - 4 } & інтолерантний & середній & толерантний \\
\hline Адаптивні здібності у взаємодії з людьми & 4,5 & 47,3 & 48,2 \\
\hline Категоричність або консерватизм в оцінках людей & 5,9 & 44,3 & 49,8 \\
\hline Уміння вибачати іншому його помилки & 3,2 & 42,7 & 54,0 \\
\hline $\begin{array}{l}\text { Уміння приховувати неприємні почуття при } \\
\text { взаємодії }\end{array}$ & 7,1 & 42,4 & 50,5 \\
\hline $\begin{array}{l}\text { Уміння розуміти та приймати індивідуальність } \\
\text { іншого }\end{array}$ & 1,9 & 38,3 & 59,7 \\
\hline Нетерпимість до емоційних станів партнера & 5,8 & 37,1 & 57,1 \\
\hline Схильність перевиховувати партнера & 3,9 & 36,8 & 59,4 \\
\hline Схильність підганяти партнерів під себе & 3,2 & 36,2 & 60,5 \\
\hline $\begin{array}{l}\text { Тенденції оцінювати інших, орієнтуючись на себе } \\
\text { в якості еталону }\end{array}$ & 4,5 & 33,4 & 62,1 \\
\hline Загальний показник комунікативної толерантності & 1,0 & 55,3 & 43,7 \\
\hline
\end{tabular}

При цьому значна частина фахівців виявляє нетерпимість до емоційних станів партнера (клієнта) (5,8\%), є категоричними або консервативними в оцінках оточуючих людей (в тому числі й клієнтів), здебільшого оцінюючи їх, орієнтуючись на себе в якості еталону (4,5\%). Це ймовірно зумовлено слабко розвинутими адаптивними здібностями у взаємодії з людьми (4,5\%), уміннями вибачати іншим їхні помилки $(3,2 \%)$, розуміти та приймати індивідуальність іншого $(1,9 \%)$, схильні «підганяти» партнерів під себе (3,2\%) та перевиховувати їх $(3,9 \%)$.

За результатами дисперсійного аналізу виявлено особливості комунікативної інтолерантності фахівців соціальної роботи залежно від статі, місця проживання. Так, зокрема, виявлено, що фахівці чоловічої статі характеризуються вищим рівнем комунікативної інтолерантності, ніж фахівці жіночої статі (рuc. 1). 


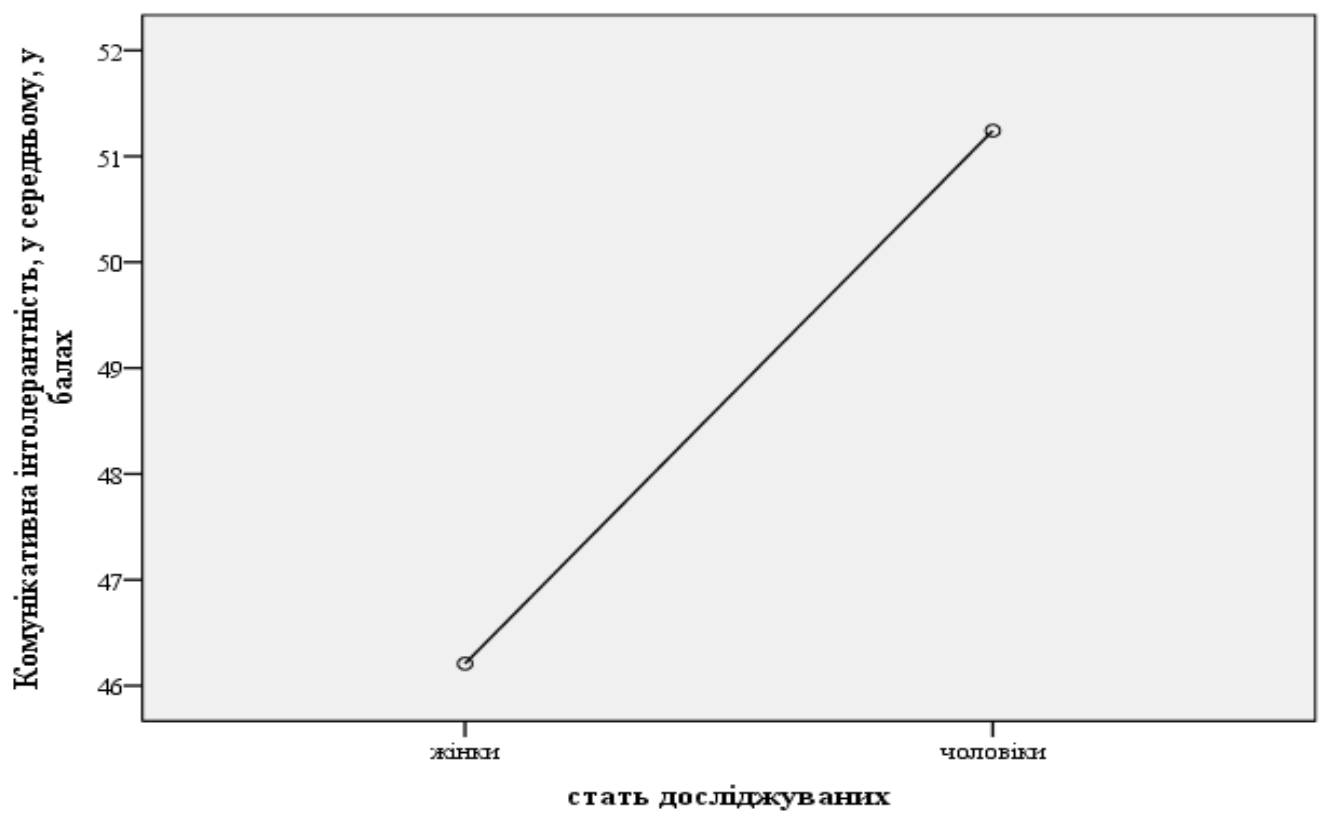

\section{залежно від статі}

Рис. 1. Особливості комунікативної інтолерантності фахівців соціальної роботи

Як видно з рис. 1, у чоловіків середній показник комунікативної інтолерантності вище i складає 51,2 бала проти 46,3 бала у жінок $(\mathrm{p} \leq 0,01)$.

Такі результати отримані за рахунок того, що фахівці чоловічої статі більше, ніж жінки, схильні оцінювати інших, орієнтуючись на себе в якості еталону ( $\mathrm{p} \leq 0,01)$; $\epsilon$ більш категоричними або консервативними в оцінках людей $(\mathrm{p} \leq 0,01)$; нетерпимими до їхніх несприятливих емоційних станів ( $\mathrm{p} \leq 0,01)$; менш, ніж жінки, здатні вибачати інших за помилки $(\mathrm{p} \leq 0,05)$; мають нижчі адаптивні здібності у взаємодії з людьми $(\mathrm{p} \leq 0,01)$.

Натомість, жінки менш, ніж чоловіки, виявляють уміння приховувати неприємні почуття у процесі взаємодії з клієнтами $(\mathrm{p} \leq 0,01)$.

Одержані нами результати узгоджуються з даними інших дослідників щодо вищого рівня розвитку комунікативних якостей жінок порівняно з чоловіками і можуть бути поясненні через гендерні особливості їхньої взаємодії, що зумовлюють жінок жити в більш структурованому, нормативному світі і відповідно бути більш комформними [В. Баранюк [2], Р. Вайнола [7], I. Кошлань [10], I. Дерябіна, А. Скок [12; 13] та ін.].

Крім того, досліджено особливості комунікативної інтолерантності фахівців соціальної роботи залежно від місця проживання, хоча в цілому відмінностей не виявлено, але вони наявні за окремими показниками. Так, уміння розуміти і приймати індивідуальність іншого та приховувати неприємні почуття у процесі взаємодії у фахівців з соціальної роботи $(\mathrm{p} \leq 0,05)$ у сільській місцевості розвинуті недостатньо, порівняно з фахівцями, які працюють у соціальних службах у місті (рис. 2).

На рис. 2 представлено особливості комунікативної інтолерантності фахівців соціальної роботи залежно від уміння приховувати неприємні почуття у процесі взаємодії у фахівців 3 соціальної роботи. Якщо в середньому комунікативна інтолерантність фахівців соціальної роботи, пов'язана з уміннями приховувати неприємні почуття у процесі взаємодії з клієнтами, у сільській місцевості складає 5,9, то в місті $-5,3$ (p $\leq 0,05)$.

Це, на нашу думку, зумовлено соціально-психологічними відмінностями у стосунках, жорсткою заданістю в селі, ціннісними орієнтаціями, психотипом сільського жителя, який відрізняється певним консерватизмом, серйозністю, повільністю, схильністю до традицій, терпимістю, невеликими вимогами до побуту, дбайливим ставленням до природи. 
Крім того, встановлено статистично значущі відмінності комунікативної толерантності фахівців із соціальної роботи залежно від стадій професійного становлення (рuc. 3 ).

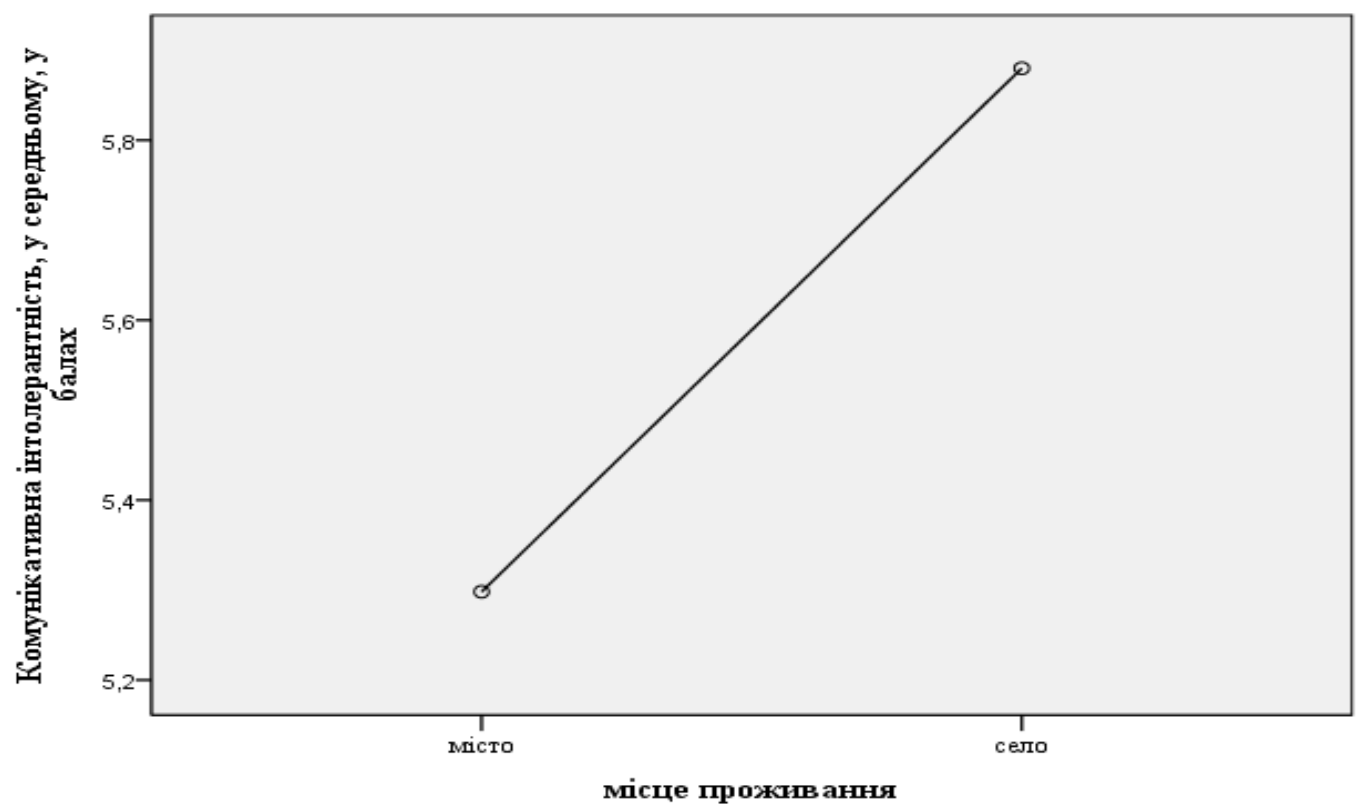

Рис. 2. Особливості комунікативної інтолерантності фахівців соціальної роботи залежно від уміння приховувати неприємні почуття у процесі взаємодії у фахівців з соціальної роботи

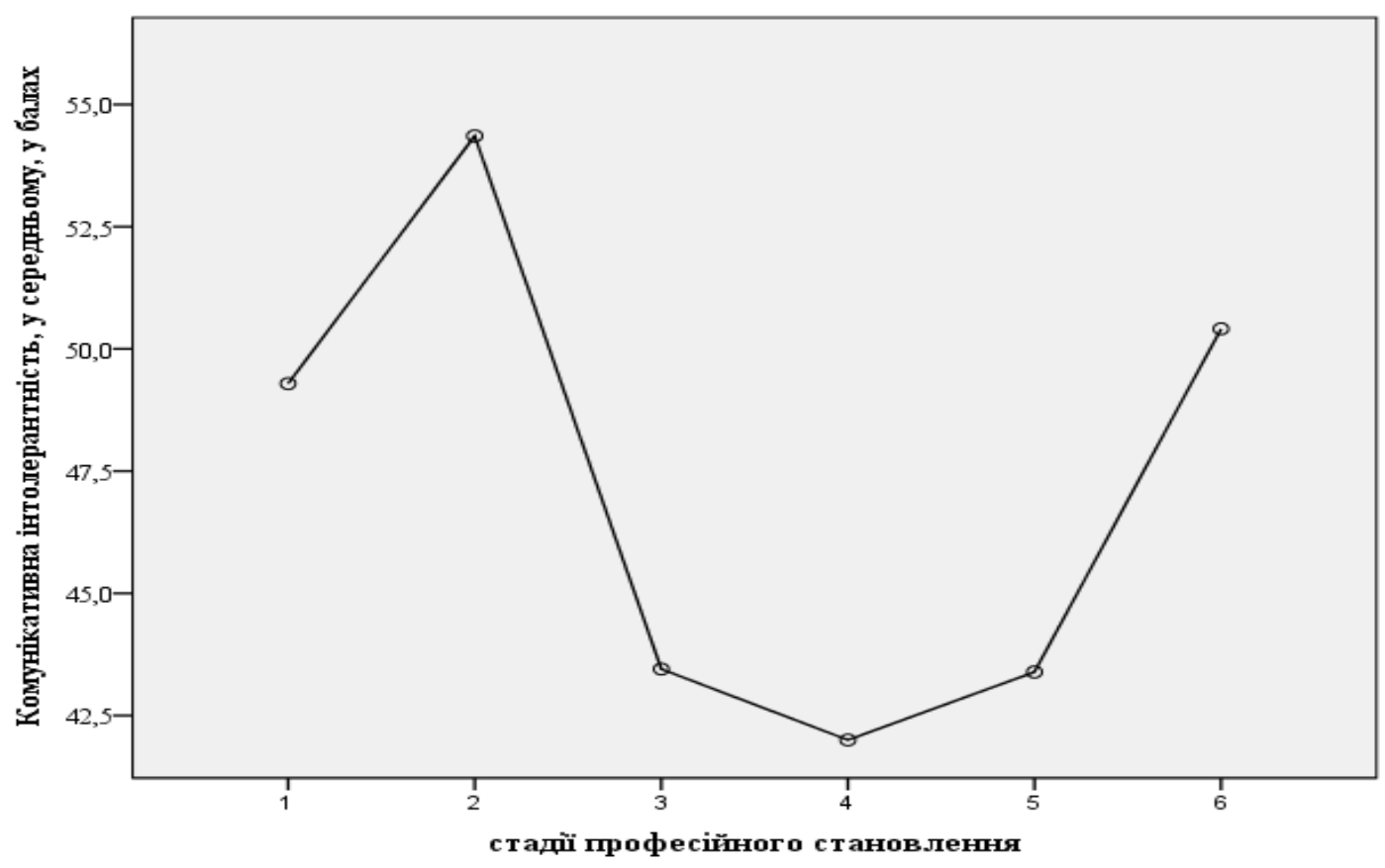

Рис. 3. Особливості комунікативної толерантності фахівців соціальної роботи залежно від стадій професійного становлення

Примітка: 1 - стадія самовизначення в якості фахівця; 2 - стадія самопроектування (життєконструювання) професійного шляху; 3 - саморегуляція у професійній діяльності; 4 саморозвиток, самоствердження та самовдосконалення у професійній діяльності; 5 - самореалізація фахівця як професіонала, досягнення «акме»; 6 - рефлексія професійного досвіду і самотворення смислу подальшого життєвого шляху. 
Як видно 3 рис. 3, показник комунікативної толерантності розвинутий недостатньо, особливо це стосується фахівців на стадіях самовизначення, самопроектування і післятрудовій стадії. Зокрема, середній показник комунікативної інтолерантності на цих стадіях становить 49,3, 54,4 і 50,4 бали відповідно. Натомість на інших стадіях цей показник значно менший і складає: на стадії саморегуляції - 43,5; саморозвитку, самоствердження та самовдосконалення - 42,0; стадії самореалізації - 43,4 бала $(\mathrm{p} \leq 0,01)$.

Такі результати отримані за рахунок того, що молоді фахівці і представники післятрудової стадії більш категоричні в оцінках людей $(\mathrm{p} \leq 0,01)$, не вміють вибачати іншим їхні помилки $(\mathrm{p} \leq$ $0,01)$, у них менш виражені адаптивні здібності у взаємодії з людьми $(\mathrm{p} \leq 0,01)$ і більша схильність перевиховувати людей $(\mathrm{p} \leq 0,01)$.

Натомість, фахівці на післятрудовій стадії характеризуються більш вираженим умінням приховувати неприємні почуття при взаємодії $(\mathrm{p} \leq 0,01)$.

Подібність показників молодих фахівців і фахівців на післятрудовій стадії зумовлена різними причинами, зокрема особливостями соціальної ситуації розвитку на різних етапах професійного становлення, особистісними новоутвореннями, пов'язаними 3 трудовою діяльністю, поступовою зміною ціннісних орієнтацій, способу життя та соціального статусу, почуттям визначеності себе як особистості. Окрім того, і молодь, і старше покоління можуть зазнавати впливу кризової ситуації через відкриття нового змісту життя і духовних цінностей, ідентифікації з новою соціальною роллю. Результати нашого дослідження та інших науковців (Ш. Берн [3], О. Бондарчук [6], В. Бойко [4; 5], Л. Харченко [14], Francesco La Barbera [16], B. Colin [15], Michael Walzer [16] та ін.) щодо проблем зазначених осіб свідчать про унікальність цих соціальних груп, адже вони (молодь і особи на післятрудовій стадії) як активні суб'єкти власного життя потребують переоцінки попередніх цінностей і формування нових, а їхнє повноцінне життя, соціальна адаптація залежить від багатьох чинників (соціальної підтримки, участі у громадській діяльності та ін.) та особливостей життєвого шляху, потреби в саморозвитку і самореалізації, ціннісних орієнтацій тощо.

Висновки. Встановлено соціально-психологічні особливості комунікативної толерантності фахівців соціальної роботи на різних стадіях професійного становлення, виявлено недостатній рівень комунікативної толерантності загалом, встановлено гендерні особливості залежно від місця проживання. Показано, що комунікативна інтолерантність $\epsilon$ вищою у фахівців чоловічої статі порівняно з жінками, а саме: чоловіки схильні оцінювати інших, орієнтуючись на себе в якості еталону; $є$ більш категоричними або консервативними в оцінках людей; нетерпимими до їхніх несприятливих емоційних станів; менш здатні вибачати інших за помилки; мають нижчі адаптивні здібності у взаємодії з людьми; виявляють уміння приховувати неприємні почуття у процесі взаємодії з клієнтами. Виявлено особливості комунікативної інтолерантності фахівців соціальної роботи залежно від місця проживання. Хоча в цілому відмінностей не виявлено, але вони наявні за окремими показниками. Встановлено статистично значущі відмінності комунікативної толерантності фахівців із соціальної роботи залежно від стадій професійного становлення, зокрема показник комунікативної толерантності розвинутий недостатньо, особливо це стосується фахівців на стадіях самовизначення, самопроектування $\mathrm{i}$ післятрудовій стадії.

До перспектив подальшого дослідження належить організація спеціального соціальнопсихологічного супроводу щодо розвитку комунікативної толерантності у фахівців з соціальної роботи на різних стадіях професійного становлення.

\section{Список використаних джерел}

1. Балл Г. О. Актуальні методологічні питання дослідження моралі і моральної поведінки / Г. О. Балл // Соціальна психологія. - 2007. - Спеціальний випуск. - С. 8-16.

2. Балахтар В.В. Комунікативна компетентність як складова професіоналізму фахівця соціальної роботи / В. В. Балахтар // Якісна освіта в Україні: тенденції, проблеми, перспективи : м-ли Міжнародної науково-практичної конференції, (Чернівці, 26-28 жовтня 2017 року). - Чернівці : Чернівецький нац. ун-т, 2017. - 336 с.

3. Баранюк В. В. Сучасні підходи до формування професійно-комунікативної компетентності майбутніх фахівців соціальної роботи / В. В. Баранюк // Наукові записки Тернопільського національного педагогічного університетуту 
ім. В. Гнатюка. Серія : Педагогіка. - 2014. - № 4. - С. 37-42. - [Електронний ресурс]. - Режим доступу : http://nbuv.gov.ua/UJRN/NZTNPU_ped_2014_4_8

4. Берн Ш. Гендерная психология / Ш. Берн. - М. : Прайм-Еврознак, 2004. - 320 с.

5. Бойко В. В. Коммуникативная толерантность : методическое пособие / В. В. Бойко. - СПб. : МАПО, 1998. - 23 с.

6. Бойко В. В. Энергия эмоций в общении: взгляд на себя и на других / В. В. Бойко. - М. : Информационноиздательский дом «Филинъ», 1996. - 472 с.

7. Бондарчук О. І. Соціально-психологічні основи особистісного розвитку керівників загальноосвітніх навчальних закладів у професійній діяльності: монографія / О. І. Бондарчук. - К. : Наук. світ, 2008. - 318 с.

8. Вайнола Р. Х. Змістові аспекти професійної підготовки майбутнього соціального педагога у вищому навчальному закладі / Р. Х. Вайнола // Науковий часопис НПУ ім. М. П. Драгоманова : зб. наук. праць (Серія : 11 «Соціальна робота. Соціальна педагогіка»). - 2010. - Вип. 11. - С. 60-68.

9. Виноградова Е. Г. Субъектные предпосылки толерантности личности: автореф. дис. ... канд. психол. наук : 19.00.01 / Е. Г. Виноградова ; Нижегор. гос. пед. ун-т. - Сочи, 2002. - 118 с.

10. Капська А. Й. Соціальна робота : навч. посібник / А. Й. Капська. - К. : Центр навч. літератури, $2005 .-328$ с.

11. Кошлань І. Г. Специфіка комунікативної толерантності у студентів представників різних типів акцентуацій / I. Г. Кошлань, I. Г. Дерябіна // Наука і освіта : наук.-практ. журн. Півд. наук. Центру АПН України. - 2009. - № 8. С. 68-71.

12. Психодиагностика толерантности личности / Г. У. Солдатова, Л. А. Шайгерова, Т. Ю. Прокофьева, О. А. Кравцова. - М. : Смысл, 2008. - 172 с.

13. Скок А. Г. Стан вивчення змісту та основних компонентів толерантності в психології / А. Г. Скок // Актуальні проблеми психології. Соціальна психологія. Психологія управління. Організаційна психологія : зб. наук. Праць Інституту психології ім. Г. С. Костюка НАПН України / за ред. С. Д. Максименка, Л. М. Карамушки. - К. : А. С. К., 2005. - Ч. 14 - С. 143-147.

14. Скок А. Г. Комунікативна толерантність викладача вищого навчального закладу / А. Г. Скок // Актуальні проблеми психології. Соціальна психологія. Організаційна психологія. Економічна психологія. - К. : Інститут психології імені Г. С. Костюка, 2005. - Т. 1. - Ч. 15. - С. 113-117.

15. Харченко Л. П. Комунікативна толерантність соціального педагога як компонент його етичної культури / Л. П Харченко // Педагогічні науки / Соціальна педагогіка [Електронний ресурс]. - Режим доступу : http://www.rusnauka.com/5_SWMN_2012/Pedagogica/6_100892.doc.htm

16. Colin, B. Grant Rethinking communicative interaction: New interdisciplinary horizons / Colin B. Grant - Amsterdam \& Philadelphia: John Benjamins, 2003. - P. 325.

16. La Barbera. Educating to Tolerance: Effects of Communicating Social Psychology Research Findings / La Barbera // Europe’s Journal of Psychology. - 2015. - Vol 11. - №3. - P. 476-483 [Electronic Resourse]. - Retrieved from : https://ejop.psychopen.eu/article/view/888

17. Walzer, Michael. Five Regimes of Toleration / Michael Walzer // New Haven and London, Yale University Press. - P. $\begin{array}{lllll}157-163 & \text { [Electronic } & \text { Resourse]. } & \text { Retrieved } & \text { from }\end{array}$

http://www.rect.muni.cz/summerschool/New_Europe/Module_3/Session\%202/7_12_11_Walzer.pdf

\section{Spysok vykorystanykh dzherel}

1. Ball H. O. Aktualni metodolohichni pytannia doslidzhennia morali i moralnoi povedinky / H. O. Ball // Sotsialna psykholohiia. - 2007. - Spetsialnyi vypusk. - S. 8-16.

2. Balakhtar V. V. Komunikatyvna kompetentnist yak skladova profesionalizmu fakhivtsia sotsialnoi roboty / V. V. Balakhtar // Yakisna osvita v Ukraini: tendentsii, problemy, perspektyvy : m-ly Mizhnarodnoi naukovo-praktychnoi konferentsii, (Chernivtsi, 26-28 zhovtnia 2017 roku). - Chernivtsi : Chernivetskyi nats. un-t, 2017. - 336 s.

3. Baraniuk V. V. Suchasni pidkhody do formuvannia profesiino-komunikatyvnoi kompetentnosti maibutnikh fakhivtsiv sotsialnoi roboty / V. V. Baraniuk // Naukovi zapysky Ternopilskoho natsionalnoho pedahohichnoho universytetutu im. V. Hnatiuka. Seriia : Pedahohika. - 2014. - № 4. - S. 37-42. - [Elektronnyi resurs]. - Rezhym dostupu : http://nbuv.gov.ua/UJRN/NZTNPU_ped_2014_4_8

4. Bern Sh. Gendernaja psihologija / Sh. Bern. - M. : Prajm-Evroznak, 2004. - 320 s.

5. Bojko V. V. Kommunikativnaja tolerantnost' : metodicheskoe posobie / V. V. Bojko. - SPb. : MAPO, 1998. - $23 \mathrm{~s}$.

6. Bojko V. V. Jenergija jemocij v obshhenii: vzgljad na sebja i na drugih / V. V. Bojko. - M. : Informacionno-izdatel'skij dom «Filin», 1996. $-472 \mathrm{~s}$.

7. Bondarchuk O. I. Sotsialno-psykholohichni osnovy osobystisnoho rozvytku kerivnykiv zahalnoosvitnikh navchalnykh zakladiv u profesiinii diialnosti: monohrafiia / O. I. Bondarchuk. - K. : Nauk. svit, 2008. - 318 s.

8. Vainola R. Kh. Zmistovi aspekty profesiinoi pidhotovky maibutnoho sotsialnoho pedahoha u vyshchomu navchalnomu zakladi / R. Kh. Vainola // Naukovyi chasopys NPU im. M. P. Drahomanova : zb. nauk. prats (Seriia : 11 «Sotsialna robota. Sotsialna pedahohika»). - 2010. - Vyp. 11. - S. 60-68.

9. Vinogradova E. G. Sub\#ektnye predposylki tolerantnosti lichnosti: avtoref. dis. ... kand. psihol. nauk : 19.00 .01 / E. G. Vinogradova ; Nizhegor. gos. ped. un-t. - Sochi, 2002. - 118 s.

10. Kapska A. Y. Sotsialna robota : navch. posibnyk / A. Y. Kapska. - K. : Tsentr navch. literatury, 2005. - 328 s. 
11. Koshlan I. H. Spetsyfika komunikatyvnoi tolerantnosti u studentiv predstavnykiv riznykh typiv aktsentuatsii / I. H. Koshlan, I. H. Deriabina // Nauka i osvita : nauk.-prakt. zhurn. Pivd. nauk. Tsentru APN Ukrainy. - 2009. - № 8. - S. 6871.

12. Psihodiagnostika tolerantnosti lichnosti / G. U. Soldatova, L. A. Shajgerova, T. Ju. Prokof'eva, O. A. Kravcova. - M. : Smysl, 2008. - 172 s.

13. Skok A. H. Stan vyvchennia zmistu ta osnovnykh komponentiv tolerantnosti v psykholohii / A. H. Skok // Aktualni problemy psykholohii. Sotsialna psykholohiia. Psykholohiia upravlinnia. Orhanizatsiina psykholohiia : zb. nauk. Prats Instytutu psykholohii im. H. S. Kostiuka NAPN Ukrainy / za red. S. D. Maksymenka, L. M. Karamushky. - K. : A. S. K., 2005. - Ch. $14-$ S. 143-147.

14. Skok A. H. Komunikatyvna tolerantnist vykladacha vyshchoho navchalnoho zakladu / A. H. Skok // Aktualni problemy psykholohii. Sotsialna psykholohiia. Orhanizatsiina psykholohiia. Ekonomichna psykholohiia. - K. : Instytut psykholohii imeni H. S. Kostiuka, 2005. - T. 1. - Ch. 15. - S. 113-117.

15. Kharchenko L. P. Komunikatyvna tolerantnist sotsialnoho pedahoha yak komponent yoho etychnoi kultury / L. P Kharchenko // Pedahohichni nauky / Sotsialna pedahohika [Elektronnyi resurs]. - Rezhym dostupu : http://www.rusnauka.com/5_SWMN_2012/Pedagogica/6_100892.doc.htm

16. Colin, B. Grant Rethinking communicative interaction: New interdisciplinary horizons / Colin B. Grant - Amsterdam \& Philadelphia: John Benjamins, 2003. - P. 325.

16. La Barbera. Educating to Tolerance: Effects of Communicating Social Psychology Research Findings / La Barbera // Europes Journal of Psychology. - 2015. - Vol 11. - №3. - R. 476-483 [Electronic Resourse]. - Retrieved from : https://ejop.psychopen.eu/article/view/888

17. Walzer, Michael. Five Regimes of Toleration / Michael Walzer // New Haven and London, Yale University Press. - P. $\begin{array}{ccccc}157-163 & \text { [Electronic } & \text { Resourse]. } & \text { Retrieved }\end{array}$ http://www.rect.muni.cz/summerschool/New_Europe/Module_3/Session\%202/7_12_11_Walzer.pdf

Balahtar, V.V. Social and psychological features of social workers' communicative tolerance at different stages of professional development. The article outlines the social and psychological characteristics of communicative tolerance among social workers at different stages of their professional development. The author has found that social workers have mostly low communicative tolerance, with men being more intolerant than women: men tended to evaluate others using themselves as a benchmark, were more categorical / conservative in assessing people and more intolerant to their negative emotional states, less able to forgive people, less adaptive when interacting with people as well as better masked their negative attitudes to customers. The author discusses the features of social workers' communicative intolerance in relation to their place of residence, although the features differ only on some indicators. Social workers' communicative tolerance had statistically significant relationships with the stages of their professional development (professional self-determination stage, self-design (life-design) stage, professional self-regulation stage, professional self-development and self-affirmation stage, professional self-realization stage, post-employment (professional experience reflection and retirement designing) stage): communicative tolerance was poorly developed in the social workers at the self-determination and self-design and post-employment stages.

Key words: communicative tolerance, intolerance, social worker, stages of professional development, self-determination, self-regulation, self-design, self-affirmation, self-improvement, self-realization, reflection.

\section{Відомості про автора}

Балахтар Валентина Візіторівна, кандидат педагогічних наук, доцент кафедри педагогіки та соціальної роботи Чернівецького національного університету імені Юрія Федьковича, м. Чернівці, Україна.

Balakhtar, Valentyna Vizitorivna, Candidate of Pedagogical Sciences, Associate Professor, Department of Pedagogy and Social Work of the Yuriy Fedkovych Chernivtsi National University, Chernivtsi, Ukraine.

E-mail: v.balakhtar@chnu.edu.ua 